\title{
Pelaksanaan dokumentasi asuhan keperawatan \\ di ruang inap
}

Indah Pandiangan

Indahpandiangan13@gmail.com

\section{Latar belakang}

Bentuk pelayanan keperawatan merupakan bagian integral dari pelayanan kesehatan yang bisa menjadi tolak ukur keberhasilan dalam pencapaian tujuan suatu rumah sakit. Kualitas pelayanan keperawatan berjalan dengan baik apabila proses keperawatan yang dilaksanakan terstruktur dengan baik. Kualitas pelayanan yang baik akan meningkatkan kepuasan pasien dan keluarga demikian juga sebaliknya jika pasien dan keluarga tidak puas maka akan meninggalkan rumah sakit bila kualitas pelayanan buruk.dalam meningkatkan kualitas pelayanan yang baik dibutuhkan penatalaksanaan pendokumentasian asuhan keperawatan pada pasien oleh perawat dengan begitu dapat lebih mudah melayani serta memberikan tindakan keperawatan berkualitas tinggi dan profesional.

Salah satu upaya untuk meningkatkan pelayanan keperawatan yang bermutu dan profesional adalah dengan menerapkan model asuhan keperawatan profesional metode tim yang memungkinkan perawat profesional mengatur dalam pemberian asuhan keperawatan termasuk lingkungan untuk menopang pemberian asuhan tersebut. Pengembangan model asuhan keperawatan profesional metode tim dikembangkan untuk menjawab tantangan terhadap kualitas pelayanan dan asuhan keperawatan yang dirasakan belum memuaskan. Model asuhan keperawatan profesional metode tim telah dilaksanakan di berbagai negara termasuk rumah sakit di Indonesia. Dengan dokumentasi keperawatan merupakan aspek penting yang perlu ditingkatkan. Dokumentasi keperawatan menjadi salah satu fungsi yang paling penting dari perawat.

\section{Metode}

Metode yang digunakan dari kajian ini adalah dengan metode literasi dengan cara melihat dari sumber jurnal maupun buku serta e-book online dengan sumber pelaksanaan pendokumentasian asuhan keperawatan di Rumah Sakit. Metode ini dapat lebih mudah dengan 
melihat sumber dari jurnal serta membandingkan dari jurnal yang lainnya dari 10 tahun terakhir. Dengan metode ini dapat disimpulkan membuat kajian ini tanpa plagiat ataupun meniru karya orang lain.

\section{Hasil}

Dokumentasi keperawatan merupakan aspek penting yang perlu ditingkatkan. Dokumentasi keperawatan menjadi salah satu fungsi yang paling penting dari perawat sistem pelayanan kesehatan mengharuskan adanya pendokumentasian karena dapat menjamin kelangsungan perawatan, dapat berfungsi sebagai bukti hukum dari proses perawatan dan mendukung evaluasi kualitas perawatan pasien, perawat yang kurang patuh dalam pendokumentasi asuhan keperawatan akan berakibat pada rendahnya mutu kelengkapan dokumentasi asuhan keperawatan. Pendokumentasian asuhan keperawatan yang tidak dilakukan dengan lengkap dapat menurunkan mutu pelayanan keperawatan karena tidak dapat menilai sejauh mana tingkat keberhasilan asuhan keperawatan yang telah diberikan.

Dalam menerapkan upaya untuk meningkatkan pelayanan keperawatan yang bermutu dan profesional adalah dengan menerapkan model asuhan keperawatan profesional metode tim yang memungkinkan perawat profesional mengatur dalam pemberian asuhan keperawatan. Penerapan model praktek keperawatan profesional dalam pemberian asuhan kepada pasien membutuhkan metode dan sistem tertentu termasuk sarana sumber daya manusia dan peralatan yang memadai sesuai tindakan prosedur yang sudah ditetapkan oleh pihak Rumah Sakit dalam hal pendokumentasian asuhan keperawatan.

Dalam pengembangan model asuhan keperawatan profesional ada tiga aspek yang perlu dikembangkan yaitu ketenagaan, sistem pemberian asuhan keperawatan, dan dokumentasi keperawatan. Pengembangan model asuhan keperawatan profesional metode tim dimaksudkan untuk menjawab tantangan terhadap kualitas pelayanan dan asuhan keperawatan perawat yang dirasakan belum memuaskan. Oleh karena itu pentingnya perawat harus menerapkan sistem pendokumentasian asuhan keperawatan terkait tindakan bentuk pelayanan keperawatan yang sudah diberikan pada pasien ketika di Rumah Sakit. 


\section{Pembahasan}

Dokumentasi keperawatan merupakan informasi tertulis tentang status dan perkembangan kondisi klien serta semua kegiatan asuhan keperawatan yang dilakukan oleh perawat. Dengan adanya pendokumentasian asuhan keperawatan merupakan suatu bentuk tindakan dalam pelayanan asuhan keperawatan yang diberikan oleh perawat kemudian dituliskan dalam bentuk laporan yang sesuai dengan kejadian atau tindakan yang sudah dilakukan oleh perawat saat merikan pelayanan kesehatan kepada klien atau pasien di Rumah sakit.

Kualitas dalam bentuk pelayanan ditentukan oleh manajemen asuhan keperawatan pelaksanakan asuhan keperawatan dengan menggunakan metode proses keperawatan untuk menyelesaikan masalah pasien, antara pasien dan perawat berhubungan secara langsung dalam pengelolaan asuhan keperawatan.

Penerapan model praktek keperawatan profesional dalam pemberian asuhan kepada pasien membutuhkan metode dan sistem tertentu termasuk sarana sumber daya manusia dan peralatan yang memadai misalnya kualifikasi sumber daya manusia dalam usaha mencapai peningkatan kesehatan dengan penekanan pada upaya pelayanan kesehatan yang memungkinkan setiap individu mencapai kemampuan hidup sehat dan produktif.

Dokumentasi keperawatan dalam bentuk dokumen asuhan keperawatan merupakan salah satu alat pembuktian atas perbuatan perawat selama menjalankan tugas pelayanan keperawatan. Sehingga dokumentasi asuhan keperawatan menjadi hal yang penting sebagai alat bukti tanggung jawab dan tanggung gugat dari perawat dalam menjalankan tugasnya. Perawat profesional dihadapkan pada suatu tuntutan tanggung jawab yang lebih tinggi dan tanggung gugat setiap tindakan yang dilaksanakan, artinya intervensi keperawatan yang diberikan kepada klien harus dihindari terjadinya kesalahankesalahan dengan pendekatan proses keperawatan dan pendokumentasian asuhan keperawatan yang akurat dan benar. Mutu asuhan keperawatan sangat mempengaruhi kualitas pelayanan kesehatan dan menjadi salah satu faktor penentu citra institusi pelayanan di mata masyarakat, kualitas pelayanan keperawatan juga akan meningkatkan kepuasan pasien. Untuk mempertahankan dan meningkatkan kualitas asuhan keperawatan diperlukan alat ukur yaitu standar asuhan keperawatan yang baku dan melalui kesepakatan oleh tenaga perawat. Salah satu usaha untuk memberikan pelayanan yang berkualitas dan profesional tersebut adalah pengembangan model asuhan keperawatan profesional metode tim yang 
memungkinkan perawat profesional mengatur dalam pemberian asuhan keperawatan termasuk lingkungan untuk menopang pemberian asuhan keperawatan di Rumah Sakit.

Model asuhan keperawatan pofesional metode tim merupakan metode pemberian asuhan keperawatan, dimana seorang perawat memimpin sekelompok tenaga perawat dalam memberikan asuhan keperawatan pada sekelompok klien melalui upaya kooperatif dan kolaboratif. Dengan metode ini metode tim didasarkan pada keyakinan bahwa setiap anggota kelompok mempunyai konstribusi dalam merencanakan dan memberikan asuhan keperawatan sehingga pada perawat timbul motivasi dan rasa tanggung jawab yang tinggi, dengan demikian diharapkan dapat meningkatkan mutu asuhan keperawatan yang baik dan profesional.

Keberhasilan suatu asuhan keperawatan kepada klien sangat ditentukan oleh pemilihan metode pemberian asuhan keperawatan profesional dengan semakin meningkatkannya kebutuhan masyarakat akan pelayanan yang bermutu tinggi dan profesional. Dengan adanya penerapan pendokumentasian asuhan keperawatan di Rumah Sakit dapat lebih mudah dalam melaporkan tindakan keperawatan dalam bentuk pelayanan yang diberikan oleh perawat agar kinerja perawat dapat profesional dan berkualitas tinggi.

\section{Penutup}

Dalam pendokumentasian asuhan keperawatan ini dapat disimpulkan dalam memberikan pelayanan ataupun suatu tindakan terhadap pasien harus di dokumentasi dalam bentuk tertulis ataupun dicatat secara tepat dan benar sesuai dengan tindakan pelayanan asuhan keperawatan yang diberikan pada pasien. Dengan diterapkannya pendokumentasian asuhan keperawatan pada pasien di Rumah Sakit diharapkan perawat lebih mampu dan teliti dalam melaporkan tindakan pelayanan dalam bentuk asuhan keperawatan. Oleh karena itu pendokumentasian keperawatan ini merupakan salah satu tindakan bentuk upaya pelayanan kepada pasien secara profesional dan berkualitas tinggi sesuai prosedur maupun tindakan yang sudah ditetapkan oleh pihak rumah sakit dalam pelayanan keperawatan dan bentuk penerapan pendokumentasian asuhan keperawatan di Rumah sakit. 


\section{Daftar Pustaka}

1. Achmad Sigit Sugiharto, B. A. (2012). Manajemen Keperawatan : Aplikasi MTKP Di Rumah Sakit. Jakarta: EGC.

2. Ali. (2009). Dasar-dasar dokumentasi keperawatan. Jakarta : EGC

3. Bahtiar, Y. (2009). Manajemen Keperawatan Dengan Pendekatan Praktis. Jakarta: Erlangga.

4. Dermawan, D. (2012). Proses Keperawatan Penerapan Konsep Dan Kerangka Kerja.

Yogyakarta: Gosyen Publising.

5. Setiadi. 2012. Konsep dan penulisan dokumentasi asuhan keperawatan. Jakarta: Salemba Medika

6. Muninjaya, 2011. Manajemen Mutu Pelayanan Kesehatan, Jakarta: EGC. hal 12-21.

7. Nursalam. 2009. Proses dan dokumentasi keperawatan. Jakarta: Salemba Medika.

8. Rohmah, N., \& Wahid, S. 2009. Proses keperawatan Arruz Media.

9. Nursalam. 2011. Manajemen keperawatan aplikasi dalam praktek keperawatan profesional. Edisi 3. Jakarta: Salemba Medika.

10. Abdurrouf, Nursalam, \& Purwaningsih. 2013. Model caring caring Islami terhadap peningkatan kepuasan pasien. Jurnal Ners, 156-16

11. Simamora, R. (2009). Dokumentasi Proses Keperawatan.

12. Simamora, R. H., Purba, J. M., Bukit, E. K., \& Nurbaiti, N. (2019). Penguatan Peran Perawat Dalam Pelaksanaan Asuhan Keperawatan Melalui Pelatihan Layanan Prima. JPPM (Jurnal Pengabdian Dan Pemberdayaan Masyarakat), 3(1), 25-31. 